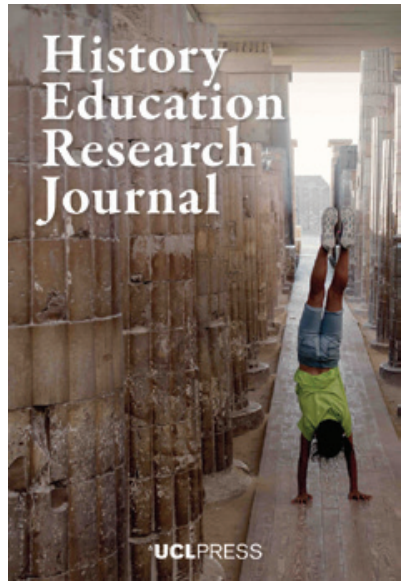

${ }^{\Perp}$ UCLPRESS

HISTORY EDUCATION RESEARCH JOURNAL

ISSN 2631-9713 (Online)

Journal homepage:

https://www.uclpress.co.uk/pages/history-educationresearch-journal

\title{
Teaching historical thinking and reasoning: Teacher beliefs
}

Súsanna Margrét Gestsdóttir(iD, Jannet van Drie(iD and Carla van Boxtel(i)

\section{How to cite this article}

Gestsdóttir, S.M., Van Drie, J. and Van Boxtel, C. (2021) 'Teaching historical thinking and reasoning: Teacher beliefs'. History Education Research Journal, 18 (1), 46-63. https://doi.org/10.14324/HERJ.18.1.04

Submission date: 13 June 2020

Acceptance date: 28 October 2020

Publication date: 20 April 2021

\section{Peer review}

This article has been peer-reviewed through the journal's standard double-blind peer review, where both the reviewers and authors are anonymized during review.

\section{Copyright}

(C) 2021 Gestsdóttir, Van Drie and Van Boxtel. This is an open-access article distributed under the terms of the Creative Commons Attribution Licence (CC BY) 4.0 https://creativecommons.org/ licenses/by/4.0/, which permits unrestricted use, distribution and reproduction in any medium, provided the original authors and source are credited.

\section{Open access}

The History Education Research Journal is a peer-reviewed open-access journal. 


\title{
Teaching historical thinking and reasoning: Teacher beliefs
}

\author{
Súsanna Margrét Gestsdóttir*, Jannet van Drie and Carla van Boxtel - \\ University of Amsterdam, the Netherlands
}

\begin{abstract}
This study aims to give an insight into the beliefs that shape history teachers' orientations towards their subject and how they approach it. We take a closer look at the beliefs of a group of teachers to see if there is a connection between those beliefs and whether and how they teach historical thinking and reasoning (HTR). HTR has been considered an important component in history teaching in many countries for some decades. Different factors may influence whether teachers are willing or able to teach it. Our main research question is: Which beliefs about goals and strategies of teaching history play a role in teachers' inclinations towards teaching historical thinking and reasoning?
\end{abstract}

Keywords: history teaching, historical thinking and reasoning, teacher beliefs, upper secondary schools

\section{Introduction}

Historical thinking and reasoning (HTR) has been considered an important component in history teaching in many countries for some decades (for example, Dawson, 1989; Lévesque and Clark, 2018; Seixas, 2008; Trautwein et al., 2017; Van Drie and Van Boxtel, 2008). It emphasizes an active building of historical knowledge and understanding in a constructivist manner, where students need to be able to establish historical significance, use primary sources, discern change and continuity, investigate cause and consequence, take historical perspectives, and fathom the ethical dimension of historical interpretations (Seixas and Morton, 2013). HTR is certainly not a prominent part of the curriculum in all countries, and many factors may influence whether it is present in the classroom. This study aims to shed light on the relation between the beliefs of a group of experienced history teachers and the extent and way in which they taught HTR. It is a part of a larger study where lessons of 27 history teachers in Icelandic upper secondary schools (almost half of all Icelandic history teachers) were analysed to gain an idea about the extent and the ways in which the teachers focused on historical thinking and reasoning (Gestsdóttir et al., 2019). To this end, an observation instrument was developed, Teach-HTR, that operationalizes the teaching of historical thinking and reasoning in observable teacher behaviour (Gestsdóttir et al., 2018). Although visible in most lessons, the fostering of HTR was not very prevalent. In order to better understand the difference between those who did and those who did not promote HTR, it is necessary to know more about their beliefs. It is important to study the teaching of experienced history teachers and bring out factors that shape their beliefs, not least since the large majority of research is addressed to pre-service or novice teachers outside the field of history education. Bringing teacher 
beliefs into the picture should aid the development of successful professionalization programmes. Little research exists in which teacher beliefs are related to actual teaching practices observed in the classroom (instead of self-reported practices). Our main research question is: Which beliefs about goals and strategies of teaching history play a role in teachers' inclinations towards teaching historical thinking and reasoning? We conducted a mixed-methods study where we supplemented already existing empirical data - that is, lessons analysis based on observations - with interviews. Eight teachers were interviewed about their beliefs, and we related this to their instructional practices. Based upon theories about the relevance of beliefs in the adoption of teaching such higher-order skills, we expect to find differences in the beliefs of teachers who teach HTR and those who do it to a lesser extent. We assume them to be related to beliefs about the nature of history, the goals of history teaching and the way students learn history.

\section{Theoretical framework}

\section{Teacher beliefs}

Different types of beliefs are discussed in literature, both about the nature and construction of knowledge in particular subjects and about the teaching of a particular subject (for example, Buehl and Alexander, 2005). It is generally acknowledged that teachers' beliefs and knowledge of their subject shape the nature of their teaching and teaching routines (Kagan, 1992; Voet and De Wever, 2016; Yilmaz, 2008). Some even claim that teacher beliefs can be 'the single most important construct in educational research' (Pajares, 1992: 329). Particularly relevant for this study are teacher beliefs about why history should be taught and how this should be done. In McCrum's (2013: 74) study, based on interviews with 11 history student-teachers, a distinction is drawn between modernist perspectives on history with an 'emphasis on an empiricist historical methodology of the objective inference of facts from sources', and postmodern perspectives where 'the past is always mediated and it is not possible for the actuality of the past to be re-presented in historical accounts'. This is in line with the interpretative nature of history, which is very prevalent in literature on historical thinking and reasoning.

Tuithof (2017) identifies eight subject-related goals of Dutch history teachers. These are: (1) cultural stock-in-trade; (2) historical reasoning; (3) an overview over time; (4) take a different perspective; (5) entertainment; (6) moral lessons; (7) to explain current affairs; and (8) as a preparation for academic or scientific thinking. However, historical thinking and reasoning are often related to other goals and are not always considered an aim in themselves. First, the development of a student's HTR contributes to a better understanding of the past (for example, Van Boxtel and Van Drie, 2013). Second, it is closely related to general skills, such as critical thinking and literacy (for example, Maggioni et al., 2004; Reisman, 2012; Wineburg, 1991). Third, many authors connect HTR to citizenship (for example, Barton and Levstik, 2004; Körber, 2015).

The teaching behaviour we focus on is based on the literature on HTR. With regard to how history should be taught, there are indications that the pedagogy advocated by those who wish to nurture historical thinking and reasoning centres on inquiry-based learning (Grant, 2018; Reisman, 2012; Wiley and Voss, 1996), working with sources (Reisman, 2012; Van Nieuwenhuyse et al., 2017) and investigation of different perspectives and interpretations (Chapman, 2011; Stradling, 2003). Explicit instruction (Nokes et al., 2007; Van Boxtel and Van Drie, 2018) is also prominent. 
Either it can include the explanations of the teacher, or it can be embedded in meaningful tasks or inquiry, such as how to explain historical phenomena, critically assess the reliability of historical sources and more. Inquiry-based tasks are usually directed at answering authentic historical questions, assuming that the past can be interpreted in various ways (Van Boxtel et al., in press). They can be combined with explicit instruction on meaningful tasks (Reisman, 2012) to form a guided inquiry learning.

With experience, teachers gradually form their views of how the subject should be taught, based on their beliefs about the nature of their subject, and about teaching in general. This is related to what Shulman (1986) calls pedagogical content knowledge. Some authors categorize teachers according to their teaching strategies. In Sweden, Nygren (2009: 3) interviewed seven experienced history teachers and subsequently described their strategies as:

1) multiperspectivity, where different points of view and interpretations of history are central; 2) narrative history, where through both major and minor stories, a chronological structure and animation of the subject of history are strived after; 3) social scientific history, which uses history to explain contemporary society through making comparisons and seeking general patterns; and 4) an eclectic strategy, which strives after varieties of an individualized teaching of history by allowing students to make their way into history in diverse ways.

This classification may be a useful tool when looking at teacher beliefs and practices. The first three categories certainly reflect well-known beliefs about the aims of history or its nature, such as interpretational history, providing a chronological overview or explaining the present. However, in the study in question, teaching strategies were related to teacher knowledge rather than teacher beliefs.

In this study, we make a distinction between teacher beliefs and teacher knowledge, focusing on the former in the sense that Pajares's (1992: 325) extensive overview reveals: that beliefs 'play a critical role in defining behaviour and organizing knowledge and information'. Quite a lot of work has been done on the beliefs of student or novice history teachers (for example, Aypay, 2011; Chan and Elliott, 2002; McCrum, 2013; VanSledright and Reddy, 2014; Virta, 2002). Less research has been done on experienced history teachers (Voet and De Wever, 2016; Tuithof et al., 2019; Yilmaz, 2008). There are indications that there is a gap/discrepancy between their beliefs and their actions. Research suggests that different beliefs about the nature of history, inclined towards either more factual or more interpretative, shape teachers' teaching approaches. Some of these approaches are more related to the teaching of HTR, such as guiding students in inquiry-based learning, working with sources, and exploring different perspectives and interpretations. The importance of explicit instruction on strategies has also been underlined.

\section{The difference between teacher beliefs and teacher behaviour}

The connection between beliefs and behaviour has been established by studies such as that of Buehl and Alexander (2005: 697), who argue that 'more sophisticated belief profiles' were followed by 'higher levels of motivation and task performance'. Nevertheless, many studies have shown how confusing teachers may find it to follow their orientation when it comes to actual classroom practice. Wansink et al. (2016) describe how student teachers who wanted to teach interpretational history did in fact teach much more factual history than they would have preferred. There was 
a clear conflict between their intentions and their practice that may partly be put down to their inexperience, although many other factors come into play, such as the requirements of the curriculum. Huijgen et al. (2019) discovered that in the observed lessons of Dutch history teachers, teachers emphasized historical contextualization to a much smaller extent than could have been expected with regard to, for example, the national curriculum, and they conclude that teachers need help to enact their intentions. Voet and De Wever (2016) discovered a disconnect between the ideas that Belgian history teachers held about inquiry-based learning and their teaching practices. Some of these could be related to contextual influences, such as availability of instructional materials, curriculum demands, the teachers' perception of their students' abilities or even their own experiences as students. VanSledright and Limón (2006) report on several studies in the United States that show the same picture, whether restricted to novice teachers or not. They mention the demands of broad curricula and simplistic assessments among the elements that push teachers towards teaching methods that are not necessarily their most preferred. In our previous study of history lessons in Iceland, teachers rarely demonstrated behaviour that could be considered as indicators of the teaching of HTR (Gestsdóttir et al., 2019). Nevertheless, they may hold beliefs in which HTR is important. It may be presumed that the explanations that other studies have found for the discrepancy between beliefs and practices apply as well to Icelandic history teachers and the teaching of HTR. These may be a curriculum that does not require the teaching of HTR, lack of experience (in the case of novice teachers) and a deficiency of knowledge or skills concerning implementation.

\section{Icelandic context}

Teachers at the very decentralized upper secondary school level in Iceland enjoy considerable autonomy in their work (see Ingvarsdóttir, 2018). The current national curriculum guide does not specify any goals for history teaching apart from the ones that apply to all subjects at all school levels. They should be based on six fundamental pillars of education: literacy, sustainability, democracy and human rights, equality, health and welfare, and creativity. Each school is responsible for including these pillars in their courses. The courses are placed on four different qualification levels where key competencies are defined. The content of courses, and the number of credit units in history that students should complete, is left to the discretion of each school, as there are no centralized examinations or other forms of external control (Ministry of Education, Science and Culture, 2014). During initial teacher education, there is little opportunity to focus on domain-specific training, since prospective history teachers belong to a larger group of students from various social subjects and pedagogy has to be taught in a generic way. Finally, it is worth mentioning that the choice of teaching materials is very restricted. For the basic courses that most schools offer, there are two sets of textbooks available, both published in the early 2000s; beyond that, the choice is extremely limited. Teachers are expected to provide many of their materials themselves. The purpose of teaching history in schools is not discussed and, to date, not much is known about actual teaching practices in history at the upper secondary level. The first comprehensive study of upper secondary schools in Iceland indicates that approximately half of all lessons in general are based on lectures, videos and so on - that is, it is teacher-centred although they may be interactive to a certain degree. This also applies to lessons in history, philosophy and ethics, all of which were grouped together in the study (Sigurgeirsson et al., 2018). 


\section{Aims and method}

\section{Aim of the study}

We use mixed methods, where data from interviews are combined with the results of observation data, gathered in a previous study, to examine the relationship between history teachers' views of their subject and how they approach it in the classroom, and their teaching of HTR in the classroom.

The research question is: Which beliefs about goals and strategies of teaching history play a role in teachers' inclinations towards teaching historical thinking and reasoning? We expect that teachers are more inclined towards teaching HTR if the following applies to them: (1) they hold nuanced beliefs about the nature of history; (2) they emphasize critical or academic thinking in their goals when teaching history; and (3) their beliefs about effective pedagogy lead them to the conclusion that students learn best through guided inquiry.

\section{Participants}

Eight teachers participated in the study. They come from a larger group of history teachers $(N=27)$ who participated in a previous study. The teachers come from seven schools. Four schools were visited in a larger study on upper secondary school practices in Iceland, where several schools were randomly sampled from stratified groups. (This research project received a grant from the University of Iceland Research Fund 2013-15 and from the NordForsk-funded Nordic Centre of Excellence: Justice through education in the Nordic countries 2013-18. Nine upper secondary schools in Iceland were randomly sampled from stratified groups of a population of 31 schools. Subcategories were made of academic, comprehensive and vocational schools, small and large schools, established and newly founded schools, and with regard to geographical location.) The remaining three schools belong to the professional network of the first author. We used purposive sampling (Palys, 2008), based on the analysis of videotaped lessons with Teach-HTR, to include a variety of teaching practices with regard to historical thinking and reasoning. Teachers were not informed about the exact focus of the study, beyond the studying of history teaching, and no attention was given to the content of the lessons. Details about education, age, experience and professional development are provided in Table 1.

Two lessons of each teacher, chosen in cooperation with them, were videotaped; four of them were with the same group of students twice, and two of them were observed

\begin{tabular}{lllll}
\hline Table 1: Study participants & & & \\
\hline Teacher & Education & $\begin{array}{l}\text { Gender/ } \\
\text { age }\end{array}$ & $\begin{array}{l}\text { Teaching experience } \\
\text { (years) }\end{array}$ & $\begin{array}{l}\text { Participation } \\
\text { in professional } \\
\text { development }\end{array}$ \\
\hline Asger & BA history & M 30 & 4 & Regularly \\
Erik & BA political science & M 51 & 24 & Regularly \\
Dag & BA history \& political science & M 32 & 5 & Regularly \\
Gunnar & MA history & M 54 & 8 & Regularly \\
Thor & MA history & M 41 & 3 & Never \\
Nanna & MA history \& archaeology & F 57 & 12 & Never \\
Ragnar & BA history & M 55 & 20 & Occasionally \\
Saga & BA history & F 35 & 8 & Occasionally \\
\hline
\end{tabular}


on the same day. All participants indicated afterwards that these lessons were fairly typical of their teaching. Both teachers and students gave their written consent to the use of the videos for research purposes. The observation instrument consisted of seven categories, and for each category there were several behavioural indicators. The categories are: (1) communicating objectives related to HTR; (2) demonstrating HTR; (3) the use of sources to support HTR; (4) presenting multiple perspectives and interpretations; (5) explicit instruction on HTR strategies; (6) engaging students in individual or group tasks that require HTR; and (7) engaging students in a wholeclass discussion that asks for HTR. (For more information about the instrument, see Gestsdóttir et al., 2018.)

We took a global rating approach - making summative judgements about the degree to which a teacher demonstrated the teaching of historical thinking and reasoning in a particular lesson. Therefore, the unit of analysis was a complete lesson. The observation instrument Teach-HTR was used in previous research to analyse the lessons and to assign scores on a Likert scale of 1-4 for each category, using more concrete indicators that could be checked as observed or not observed.

When it comes to the observed lessons of the eight participants in the current study, it is possible to distinguish between three groups (pseudonyms were assigned). The differentiation is based on if and how the teachers engaged students in HTR, either through individual or group assignments that asked for such activities, or through whole-class discussions that required the same (see Table 1; Gestsdóttir et al., 2019). The first two, Asger and Erik, did this actively; Dag, Gunnar and Thor did so to a moderate extent; Nanna, Ragnar and Saga did not actively engage students in HTR. A detailed analysis is provided in Table 2, using the scores on the 1-4 Likert scale.

\section{Data and instruments}

Semi-structured interviews (Leech, 2002) were conducted in October 2015 by the first author. A video of one lesson was sent to the teachers in advance, as well as the TeachHTR analysis of that lesson, which also included a short summary of the lesson. The purpose was to provide the opportunity to discuss particular fragments of the lesson. The participants received a brief questionnaire that asked about their reasons for becoming a teacher and about their participation in formal and informal professional development during the last five years.

The interviews lasted $40-53$ minutes, on average 45 minutes. All interviews took place at the respective schools, except one that took place via Skype. The questions focused on the teachers' view of history teaching in general (for example, 'Why teach history?'), their personal goals for history teaching (for example, 'What do you aim at in your teaching?'), how they planned their teaching activities (for example, 'Do you plan your teaching activities for each lesson or for longer units?') and if they thought that students struggled with some particular elements of learning history. Furthermore, teachers' professional identity was investigated by asking what had shaped their beliefs about history teaching, if they felt those beliefs had changed since they started their teaching career, and if they thought history teaching required some special approaches.

The analyses of the lessons by the observation instrument Teach-HTR were discussed in detail, as well as a couple of videotaped examples selected by the interviewer to sharpen some questions (for example, 'What is your aim when you address this group like that rather than providing them with the answer?'; 'What is your aim with using this particular photograph?'). 


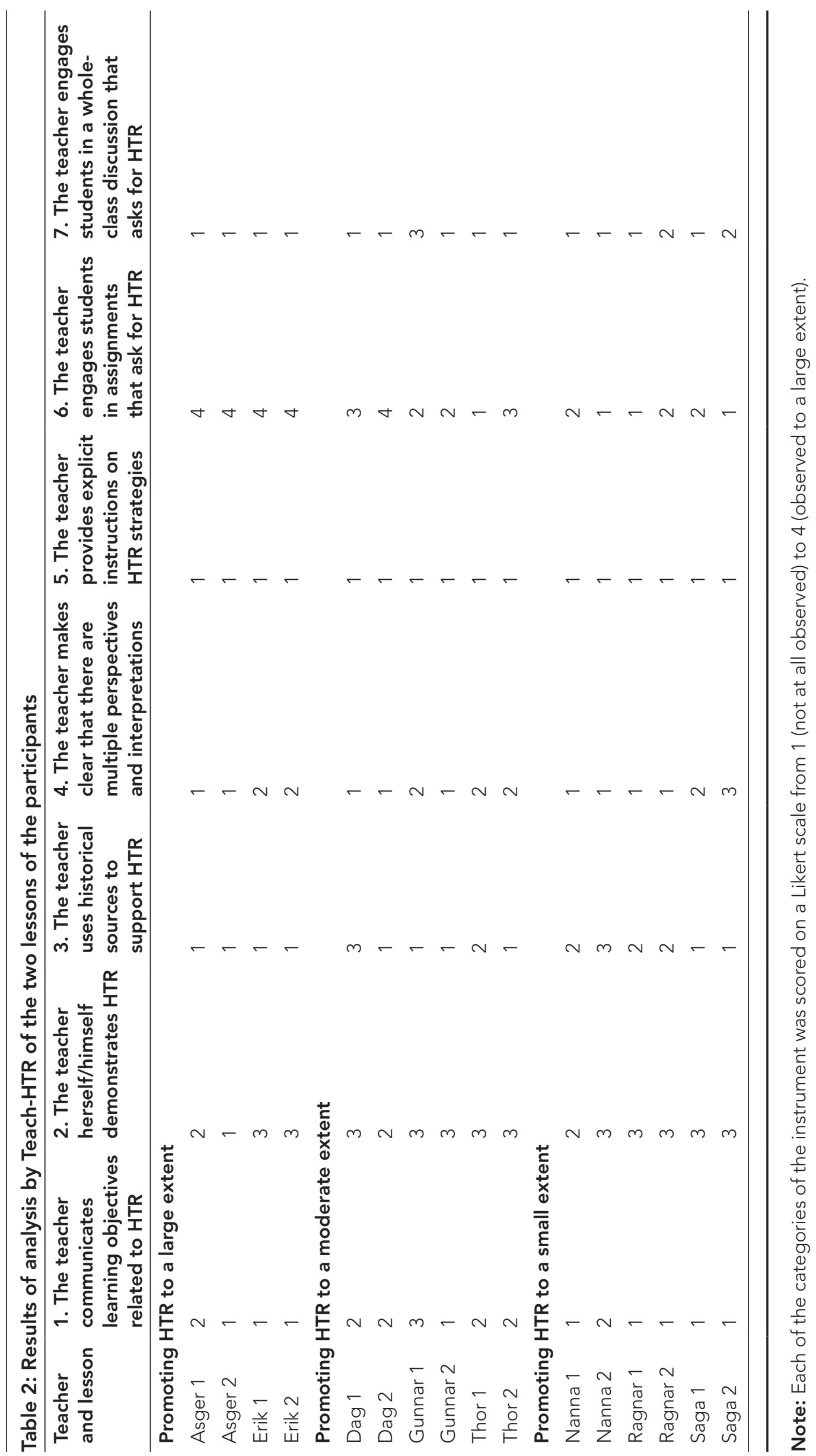




\section{Data analysis}

The aim of the data analysis was to gain an insight into teachers' beliefs about history, their goals and how they approach these in the classroom. The interviews were transcribed and analysed by the first author. A coding scheme was developed, based on both deductive and inductive coding strategies (Miles and Huberman, 1994). The coding scheme was discussed among all three authors. From the outset, the focus was clear, and the answers to several questions were to reflect: (1) the participants' goals for teaching history (why teach history?; see Table 3); and (2) their ideas about the teaching of history (how to teach history). The transcripts were divided into segments representing answers to these main questions. Categorization was developed from the literature, but also from themes that emerged during the interviews and in close cooperation with all three authors. The categorizing of goals was based on Tuithof's (2017) work: cultural stock-in-trade, historical reasoning, overview over time, different perspective, entertainment, moral lesson, to explain current affairs, and preparation for academic or scientific thinking. We added the category 'general skills' to cover goals such as training students in group work or note-taking, and combined historical skills, such as working with sources, with the category historical reasoning. Teachers' ideas about the teaching of history were grouped in nine categories, using a bottomup approach according to what they discussed in the interviews: project work with uncertain outcome, lectures, combination of lectures and students' tasks, working with sources, tasks that require recall, whole-class discussion, visual material, on-site learning and having visitors to class. Furthermore, using this categorization and the interview data, the classification of Nygren (2009) was used to characterize teachers' ideas: the categories were multi-perspectivity, narrative history, social scientific history and an eclectic strategy.

\section{Results}

In this section, we first discuss teachers' beliefs about history and their goals, and second, how they approach these in the classroom. The outcomes of the interviews are related to the observation data.

\section{Teachers' beliefs about history and their goals}

Table 2 presents the results of the analysis of the participants' lessons. Table 3 presents the goals of the teachers that emerged in the interviews. When asked about the raison d'être of history as a school subject, seven out of eight teachers mentioned being able to explain current affairs. They talked about skills, as history gives students a firm basis to stand on in society as critical thinkers. It also gives them the necessary tools to form a grounded opinion on controversial issues, and possibly even to realize that the causes or explanations for current situations are not always the expected ones.

Asger and Erik, who were considered to teach HTR to a large extent, explicitly verbalized goals related to the teaching of HTR (historical reasoning and skills, and different perspectives). Asger stressed the importance of understanding change and continuity. He struck a moral note when he expressed his opinion that students need to understand how comfortable their life is, compared with the life of previous generations or their contemporaries in other countries. He put history in a key position in the school system when saying it was crucial 'to understand why everything is as it is'. Asger said students needed to learn procedures, for example, to read academic texts as a preparation for further studies, and added that 'content is the least 


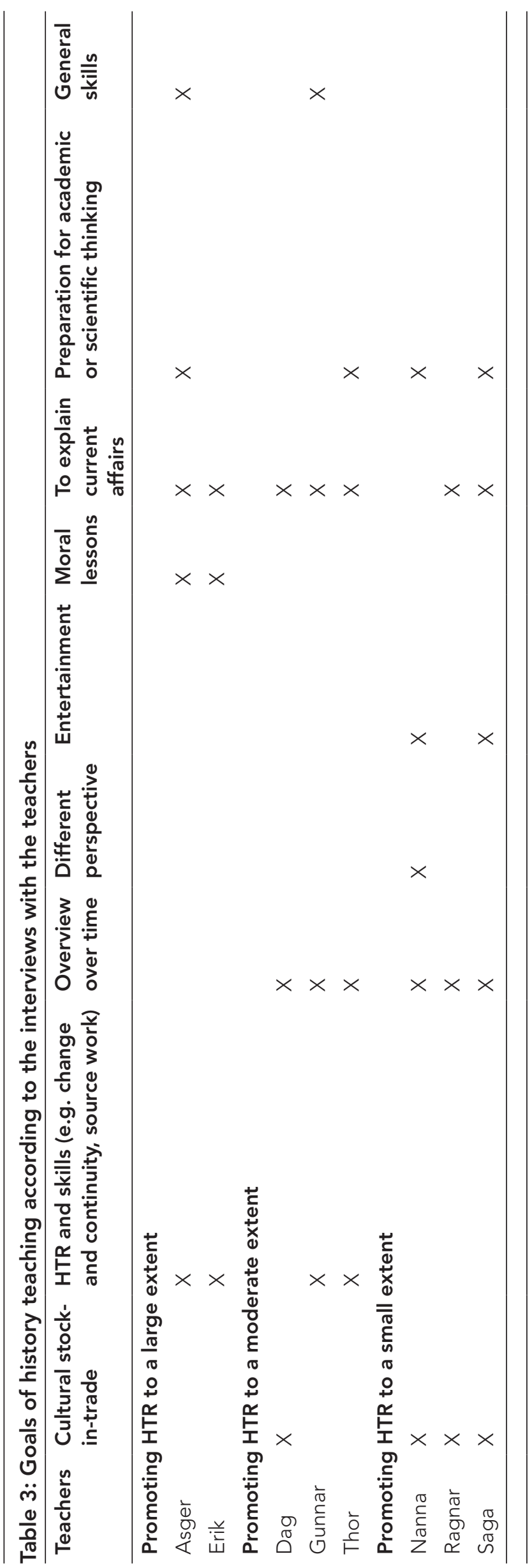


important factor'. Erik wanted students to be able to deal critically with information, to make comparisons and to understand the influence of the past, rather than adopting concrete items of historical knowledge. He said he was finally able to put a finger on his aims as a history teacher when reading Barton and Levstik's (2004) book, Teaching History for the Common Good. He did not hesitate to reduce the reading materials or topics in favour of digging deeper and emphasizing what is really of value to people living in a democratic society. During the observed lessons given by Erik, his students were working in groups on projects, and Erik's interaction with them consisted mainly of urging them to be critical thinkers. One of the groups wanted to base their project on the research question 'What are the goals of these three terrorist organizations?' Erik asked them not to use the concept 'terrorism' unless it had been justified by their investigation, and he put several questions about the term to the group. Both Asger and Erik mentioned several items that figure in the observation instrument Teach-HTR, such as asking historical questions and problematizing, discerning aspects of change and continuity, comparing historical phenomena and periods, and using information from sources as evidence in an interpretation.

Dag, Gunnar and Thor were considered to promote HTR to a moderate extent, as can be seen in Table 3. Dag did not mention any HTR goals when interviewed, but in the lessons observed, his students were working on tasks where they needed to include the different perspectives of historical actors during the Second World War. Thor contemplated that history might be useful to teach critical reading of sources, but added that it was a skill that was difficult to teach. In one of his observed lessons, he engaged students in a written task that demanded some historical thinking. Gunnar discussed the vital role that history plays in the very being of the Icelandic nation and the existence of the Icelandic language, thereby being the only teacher alluding to nationalistic views. He added that people could not think critically and be enlightened without historical knowledge. Gunnar referred to general skills when he said that students needed to practise their note-taking more than discussions or group work, which he felt they were quite good at already. However, he engaged his students in whole-class discussions where they had to define concepts and compare them. These three teachers mentioned only a couple of items that are included in the instrument Teach-HTR, mainly regarding the use of historical sources to support HTR and assigning historical significance to persons, events or developments.

Nanna, Ragnar and Saga are the three teachers who hardly promoted HTR at all, despite Nanna's remark about the importance of seeing things from the perspective of people in the past. They wanted students primarily to gain historical knowledge, and their lessons confirmed their emphasis on transmitting it through lectures, which in the case of Nanna and Ragnar did not require any student participation. Nanna constantly felt the pressure of telling the students as much as possible: 'There's a lot of interesting stuff I haven't told you yet - what time is it? Let's do two more slides before we finish today.' She claimed it was not possible to provide students with proper cultural and historical literacy by picking out pieces of history that fitted the present: 'We need to teach everything as it was, and doing so includes Christianity.' In fact, Nanna was the only one who mentioned theology and religious history by referring to the need for familiarity with both when studying art history. Ragnar underlined the practical purpose of learning history: knowing one's society, understanding democracy and human rights, and being familiar with the development of both through time. Saga claimed that history should be taught in schools mainly because it is interesting and a good way to kindle students' interest in studying and acquiring knowledge: 'There's something wrong with you if you cannot find something of interest in history, 
right?' Ragnar's ideas about the development of democracy and human rights are the only instance where items of the instrument Teach-HTR are referred to (discerning aspects of change and continuity), besides Nanna making clear that contemporary standards should be avoided when looking at the actions of people in the past. All three advocated the goal of historical knowledge (referred to as 'overview over time' in Table 3), and both Nanna and Saga mentioned the aim of preparing their students for academic or scientific thinking.

Nanna is a clear example of a teacher whose teaching of HTR mainly consisted of items that in the observation instrument Teach-HTR belong to the category 'The teacher herself/himself demonstrates historical thinking or reasoning activities without explaining explicitly what she/he is doing or giving instructions on how to do it'. Nanna's goals for history teaching are to provide her students with cultural stock-intrade and increase their cultural literacy by transferring historical knowledge to them in an entertaining fashion. Through this, she intends to prepare them for academic or scientific training later on. Nanna was the only one of the eight teachers who did not share the goal of teaching history to explain current affairs. On the contrary, she linked it with becoming familiar not only with the historical past, but also with art and religion. Her view of history becomes clear from her statement: 'We need to teach everything as it was, and doing so includes Christianity.' She promotes empathy when she warns her students against presentism, and she urges them to look at historical events and situations from the point of view of those who experienced them first-hand. When interviewed, Nanna discussed her worries about the decrease of obligatory history courses at her school, and an increasing tendency to pick out fragments of history to teach. She described how she strived to keep up with new knowledge in the field to be able to bring it to her students, and the very positive feedback she gets from them. Nanna has a very warm and caring relationship with her students, and it is for their benefit that she puts an enormous amount of work into preparing the material she presents to them. She feels like a successful teacher whose profession brings her a lot of joy and fulfilment.

\section{Teaching approaches and beliefs about how to teach history}

The difference between the three groups of teachers becomes more salient when their beliefs about how to teach history are investigated. The lessons of those who promoted HTR the most, Asger and Erik, are clearly more student-centred than those of the others. They engaged students in tasks that were open-ended, that is, students were working with sources to build up their own historical knowledge and skills. Erik described how he struggled with this approach. He kept a diary, and explained that this helped him discover that:

I was taking too much control, we did everything on my terms, so I tried to back out of it a bit and you just have to control yourself, because the teacher who wants to have complete control is always there within me and he appears sometimes and I have to make sure to suppress him ...

The teachers demonstrated HTR when they were moving between groups of students, for example, asking historical questions or problematizing. Asger and Erik can be said to use eclectic instructional strategies, according to Nygren's (2009) categorization, that is, giving their students the opportunity to approach history in various ways.

Erik was particularly clear about his beliefs. When interviewed, he explicitly rejected the idea of striving to cover a vast amount of historical knowledge, and claimed that it was much more beneficial for the students to dig deeper into certain 
topics. This would provide them with the necessary skills to participate in a democratic society, that is, the skills required by the national curriculum guide. He referred to his own upbringing in a relatively socially deprived neighbourhood, and how he felt that school had missed the opportunity to respond to this. Erik said history teaching needed to be open, to dare to present students with open-ended tasks and lean more towards constructivism. Similarly, Asger described how he was willing to discard the previous organization of a course, if he felt that the group of students could be pushed towards more creative assignments. His own memories from school very much focused on the (rare) occasions when the class had 'done something different'.

Dag, Gunnar and Thor promoted HTR to a moderate extent. Dag's lessons were similar to Asger's and Erik's in that his students worked mainly on HTR assignments, but his beliefs had much more in common with the beliefs of those who promoted HTR to a lesser extent. It is therefore difficult to place him according to Nygren's (2009) categorization. Gunnar engaged students less in HTR tasks than Asger and Erik, but, even so, his lessons were more student-centred than not, and he took care that his own direct contribution never exceeded a quarter of the lessons. He frequently drew comparisons between the eighteenth and nineteenth centuries and the present; in particular, he strived to take examples from the upcoming referendum on Scottish independence to explain the nationalism of previous centuries. His instructional strategies may be placed within social scientific history, that is, making use of history to promote an understanding of the present (Nygren, 2009). Thor explicitly mentioned a specific historical skill he wanted to promote - referring to sources to support an argument and making a correct list of references (the latter being more a general skill than an HTR skill). However, his instructional strategies were mainly teacher-centred, only engaging students in a task that asked for HTR up to a point, and they can be classified as narrative history (Nygren, 2009). Thor's and Dag's beliefs were not very pronounced. They wanted to create a good atmosphere in their lessons, and they claimed to be content if their students gained some historical knowledge and skills along the way. Gunnar was absolutely firm about the important role of historical knowledge: 'In a society where the citizens are expected to contribute to political discourse ... where they are expected to be critical as well as enlightened, they cannot take a stand on current controversial issues without some historical knowledge.' When discussing whether teaching history required some special approaches, all three answered in rather unspecified terms that could, in fact, apply to teaching in general. They did not seem convinced that it was so ('not sure', 'not necessarily'), and consequently they steered the conversation more towards what had worked well for them as teachers in general. They tended rather to look at how history could serve other aims.

Narrative history would apply to the instructional strategies of Nanna, Ragnar and Saga, who stayed mainly within category 2 (demonstration of HTR). In contrast to Asger and Erik, this took place ex cathedra, when they were giving lectures. Their lessons were teacher-centred, especially those of Nanna and Ragnar, who did not require any participation from their students when they lectured (although they welcomed it when it happened). They regarded placing an emphasis on visual material, such as photographs and documentaries, as a necessary element of a good lecture, and they tended to engage students mainly in tasks with a fixed outcome. Nanna claimed that it was necessary to make history exciting, and that the best way to spark students' interest was to visualize history and to weave images, documentaries and films into a good teacher lecture.

All of the teachers were perceptive of students' needs, and had opinions on how to meet them. Their ideas did not demonstrate a clear difference concerning their 
promotion of HTR, as is shown by the variety of their thoughts about whether history students struggled with something in particular. Asger, Gunnar and Nanna mentioned the problem of understanding concepts, for example, monarchy, independence, monopoly and democracy. Two of them blamed this partly on students' poor reading comprehension skills and limited vocabulary. Thor said that students struggled with remembering dates, and that he did not expect them to learn any. Erik was the only one who mentioned any difficulties for students that related to HTR, when he described how challenging it is for students to understand continuity and change over time, especially if this is mainly demonstrated by using methods such as diagrams. He preferred 'luring' students towards investigating by using personal examples, for example, in social history. Dag and Saga complained about superficiality, either in courses that are supposed to cover vast spans of time and many topics, or in students' work.

When asked if they felt that their teaching had changed since they started teaching, the response was quite varied. This is not surprising, given the fact that the range of teaching experience was 3 to 24 years (on average, 10.6 years). The replies show how teachers become professionals by becoming more confident in their daily practices, but the responses do not shed light on the development of history teachers per se. The comments of five of the teachers (Erik, Dag, Gunnar, Ragnar and Thor) implied that their teaching had become more student-centred. Ragnar said:

I think I can safely say that I have changed, and when I began teaching it was much more direct teaching, me preaching more or less all the time. Maybe the students did e.g. one presentation, and then it was back to my preaching, using marathon slideshows. This has diminished considerably.

When asked why, he referred to this approach being considered old-fashioned, as well as the student group having changed and being less receptive to lecturing. However, he and Thor still considered favouring a teacher-centred approach. The opposite applied to Asger, who did not really feel he had changed as a teacher during his four years in the classroom. From the beginning of his career, Asger had practised the democratic approach of giving his students a choice of topics at the start of term. Therefore, he never fully knew in advance what topics he would be teaching, and he was ready to reconsider all his plans if the group of students was so inclined and he felt he could push them further.

\section{Conclusion and discussion}

This study provided an insight into how beliefs about goals and strategies of history teaching may play a role in teachers' inclinations towards teaching historical thinking and reasoning. Teacher beliefs are implicit to a certain degree. Here, single interviews were used to elicit these beliefs. Other ways are possible, for example, reflections based on a combination of interviews and a tool such as a storyline instrument for self-expression of teachers (see Wansink et al., 2016). When the analysis of lessons with the observation instrument Teach-HTR is compared with the interviews with the eight participants, clear patterns emerge. As we divided the teachers into three groups according to the emphasis they put on teaching HTR (actively engaging students in HTR to a large, moderate or very small extent), several strands appeared.

We expected that teachers were more inclined towards teaching HTR if their beliefs about the nature of history were more nuanced. The teaching approaches of Asger and Erik, the two teachers who were considered to promote HTR to a large extent, were based on a belief in the interpretational nature of history. Moreover, they 
were the only ones who discussed the moral lessons that history could provide, as well as historical reasoning and skills. The latter they shared with Gunnar and Thor, two of those who promoted HTR to a moderate degree. In other words, they accentuated different elements from the other teachers. Furthermore, we expected teachers to be more inclined towards teaching HTR if their teaching goals emphasized critical or academic teaching. The beliefs and goals of the teachers promoting HTR to a moderate or very small extent were different from those of the others. Their goals hinged on giving an overview over time, that is, historical knowledge, and providing students with cultural stock-in-trade. Although Nanna and Saga saw the studying of history as a preparation for academic or scientific thinking (a factor also mentioned by Asger), they did not emphasize critical thinking, such as a critical use of sources, to the same degree as those who taught more HTR. We also expected that teachers were more inclined towards teaching HTR if their beliefs about effective pedagogy led them to the conclusion that students learn best through guided inquiry. Here we observed a salient difference between the three groups of teachers. Those who promoted HTR less were inclined to lecture, which is in fact where they mainly demonstrated HTR in the lessons observed, or to combine lectures with student tasks. The tasks, although varied, mainly asked for recall. This group of teachers shared the modernist perspective of history (McCrum, 2013). On the other hand, Asger and Erik favoured project work with an uncertain outcome, and working with sources. They gave their students considerable freedom in how to approach their tasks, and they pushed them towards finding their own results. Dag was the third teacher to whom this applied, whereas all the other teachers mentioned lecturing or a combination of lectures and student tasks. In general, the teaching of the first four teachers - Asger, Erik, Dag and Gunnar - was more student-centred and inquiry-based than the teaching of the others. They seem to share the postmodern perspective of history described by McCrum (2013). Participation in professional development can possibly be added to these common features, as all four participated on a regular basis, in contrast to the others, who participated only occasionally or not at all. Another study points towards a connection between profound reflection on history teaching and the teaching of historical thinking (Voet and De Wever, 2016). However, more research is needed to see if links can be established between regular professional development and the teaching of HTR. It is worth mentioning that student- or teacher-oriented approaches have no bearing on teachers' disposition towards their students; other elements of teacher beliefs beyond the scope of this study come into play concerning general interaction with students.

However, there was no pronounced difference between the three groups of teachers when asked if history teaching required some special approaches. The comment of one teacher that 'it varied from one group to another' shows the commendable ability of an experienced teacher to adapt their teaching to different students, but reveals that history teaching per se may not have been given much thought. None of the teachers delved deep into the construction of historical knowledge, and they mostly discussed teaching strategies and other pedagogical issues in very general terms, with the notable exception of Erik, who was working towards a degree in educational studies at the time. In other words, they lack the necessary language that would enable them to participate in the history educators' community of practice (Van Boxtel and Van Drie, 2017). After interviewing 12 US history teachers, Yilmaz (2008: 167) concluded that 'Their responses clearly indicated that they did not perceive the relevancy of intellectual and conceptual foundations of history as a discipline for their profession and professional development', and this applies to the Icelandic teachers as well. Voet and De Wever 
(2016: 61) reach similar conclusions when describing different teacher beliefs; only 3 out of 22 participants in their interview study 'talked about familiarizing students with the constructed nature of history', and there were indications that those who give a lot of thought to history as a subject tend to lean more towards historical reasoning skills. This finding is supported by the Icelandic sample.

The teaching of historical thinking and reasoning in Icelandic upper secondary schools is weak. Analysis of the large sample of 54 history lessons showed that the mean scores range from 1.11 to 2.76 out of 4 for the seven categories of the observation instrument Teach-HTR (Gestsdóttir et al., 2019). The interviews with the eight teachers in the present study support this result. It seems apparent that the conditions of Icelandic history teachers are not very helpful when it comes to the kind of metacognition required of skilful teachers of HTR. Neither their initial nor their inservice training imposes any such requirements on them. Initial training is very generic, and the in-service training offered to history teachers is mainly topical rather than pedagogical. The national curriculum guide and available teaching materials offer neither incentive nor help to those who might want to develop their professional expertise. The autonomy and lack of external control, while entailing unusual freedom, also deprives teachers of any constructive support.

Certain limitations of the study must be acknowledged. Our approach consisted of selecting teachers who differed in the degree to which they taught HTR according to the observation instrument Teach-HTR. We then sought patterns in beliefs across teachers. Another, more hermeneutic, approach would have been to analyse each teacher in depth, combining results from the interview and the observations, taking more into account the specific context and dynamics in the classroom. A more qualitative interpretative analysis might have cast light on how teacher beliefs are interconnected to the planning of lessons and even student learning. A different structure of the interviews and the preceding questionnaire could have served this purpose.

In fact, limited attention is paid to student behaviour in the observation instrument, only through the categories focusing on engaging students in HTR through assignments and whole-class discussion. We see our attention to teacher behaviour as a strength of the instrument used. Future research might illuminate the links between teacher beliefs, teacher behaviour and student learning.

This study has several implications for teacher education programmes and professional development. It takes a closer look than has been available until now at the relationship between the teaching of historical thinking and reasoning and the beliefs of experienced teachers. It seems apparent that certain beliefs relate more than others to teaching historical thinking and reasoning. Despite focusing on a certain way of teaching HTR, the observation instrument Teach-HTR has space for different kinds of teaching practices. It also incorporates more teacher-centred ways of instruction, such as providing historical overview and knowledge through lecturing. It might be of use in a professional development programme where HTR theories on the understanding and application of historical knowledge are used to push students towards higherorder thinking skills. It could also be used in initial teacher training to assist student teachers who wish to pay attention to their beliefs regarding the teaching of HTR in order to organize their teaching in accordance with their intentions.

\section{Notes on the contributors}

Súsanna Margrét Gestsdóttir works at the Faculty of Subject Teacher Education at the University of Iceland as chair of the Upper Secondary School Teaching Graduate 
Programme. As a history teacher at upper secondary level, she participated in the professional development of history teachers at home and abroad, as a board member and a president of EuroClio, the European Association of History and Citizenship Educators, among other roles. She will complete a PhD from the University of Amsterdam in early 2021.

Jannet van Drie is Associate Professor at the Research Institute of Child Development and Education of the University of Amsterdam, the Netherlands. Her research focuses on the learning and teaching of history.

Carla van Boxtel is Professor of History Education at the University of Amsterdam, the Netherlands. Her research focuses on the teaching and learning of history in and outside school. She has published widely about the teaching and learning of historical reasoning.

\section{References}

Aypay, A. (2011) 'The adaptation of the Teaching-learning Conceptions Questionnaire and its relationships with epistemological beliefs'. Educational Sciences: Theory \& Practice, 11 (1), $21-9$.

Barton, K. and Levstik, L.S. (2004) Teaching History for the Common Good. Mahwah, NJ: Earlbaum.

Buehl, M. and Alexander, P. (2005) 'Motivation and performance differences in students' domainspecific epistemological belief profiles'. American Educational Research Journal, 42 (4), 697-726. https://doi.org/10.3102/00028312042004697.

Chan, K. and Elliott, R.G. (2002) 'Exploratory study of Hong Kong teacher education students' epistemological beliefs: Cultural perspectives and implications on beliefs research'. Contemporary Educational Psychology, 27 (3), 392-414. https://doi.org/10.1006/ceps.2001.1102.

Chapman, A. (2011) 'Historical interpretations'. In Davies, I. (ed.), Debates in History Teaching. New York: Routledge, 96-108.

Dawson, I. (1989) 'The Schools History Project: A study in curriculum development'. The History Teacher, 22 (3), 221-38. https://doi.org/10.2307/492862.

Gestsdóttir, S.M., Van Boxtel, C. and Van Drie, J. (2018) 'Teaching historical thinking and reasoning: Construction of an observation instrument'. British Educational Research Journal, 44 (6), 960-81. https://doi.org/10.1002/berj.3471.

Gestsdóttir, S.M., Van Drie, J. and Van Boxtel, C. (2019) 'Teaching historical thinking and reasoning in upper secondary schools in Iceland: Results of an observation study'. Nordidactica: Journal of Humanities and Social Science Education, 2019 (2), 90-113. www.persistent-identifier.nl/ urn:nbn:nl:ui:29-667dc3a7-b755-4a48-a21e-28bf5c84e09d.

Grant, S.G. (2018) 'Teaching practices in history education'. In Metzger, S.A. and MacArthur Harris, L. (eds), The Wiley International Handbook of History Teaching and Learning. Hoboken, NJ: Wiley-Blackwell, 419-48. https://doi.org/10.1002/9781119100812.ch16.

Huijgen, T., Holthuis, P., Van Boxtel, C. and Van de Grift, W. (2019) 'Promoting historical contextualisation in classrooms: An observational study'. Educational Studies, 45 (4), 456-79. https://doi.org/10.1080/03055698.2018.1509771.

Ingvarsdóttir, H. (2018) 'Kennsluhættir speglaðir í ljósi sjálfræðis: Virðing, ábyrgð og traust' [Exploring autonomy: Respect, responsibility, trust]. In Jóhannsdóttir, P.J. and Porgeirsdóttir, H. (eds), Framhaldsskólinn í brennidepli. Netla, veftímarit um uppeldi og menntun. https://doi.org/10.24270/serritnetla.2019.3.

Kagan, D.M. (1992) 'Implications of research on teacher belief'. Educational Psychologist, 27 (1), 65-90. https://doi.org/10.1207/s15326985ep2701_6.

Körber, A. (2015) Historical Consciousness, Historical Competencies - and Beyond? Some conceptual development within German history didactics. Deutsches Institut für Internationale Pädagogische Forschung. https://doi.org/10.13140/RG.2.1.1524.9529.

Leech, B.L. (2002) 'Asking questions: Techniques for semistructured interviews'. Political Science \& Politics, 35 (4), 665-8. https://doi.org/10.1017/S1049096502001129.

Lévesque, S. and Clark, P. (2018) 'Historical thinking: Definitions and educational applications'. In Metzger, S.A. and MacArthur Harris, L. (eds), The Wiley International Handbook of History Teaching and Learning. Hoboken, NJ: Wiley-Blackwell, 119-48. https://doi.org/10.1002/9781119100812.ch5. 
Maggioni, L., Alexander, P. and VanSledright, B. (2004) 'At a crossroads? The development of epistemological beliefs and historical thinking'. European Journal of School Psychology, 2 (1-2), 169-97.

McCrum, E. (2013) 'History teachers' thinking about the nature of their subject'. Teaching and Teacher Education, 35 (1), 73-80. https://doi.org/10.1016/j.tate.2013.05.004.

Miles, M.B. and Huberman, A.M. (1994) Qualitative Data Analysis. Thousand Oaks, CA: Sage.

Ministry of Education, Science and Culture (2014) The Icelandic National Curriculum Guide for Compulsory Schools - with subjects areas [Aðalnámskrá grunnskóla: almennur hluti 2011: greinasvið 2013]. http://brunnur.stjr.is/mrn/utgafuskra/utgafa.nsf/RSSPage. xsp?documentld=E7DE015E63AA2F2C00257CA2005296F7\&action=openDocument (accessed 19 January 2021).

Nokes, J.D., Dole, J.A. and Hacker, D.J. (2007) 'Teaching high school students to use heuristics while reading historical texts'. Journal of Educational Psychology, 99 (3), 492-504. https://doi.org/10.1037/0022-0663.99.3.492.

Nygren, T. (2009) 'Erfarna lärares historiedidaktiska insikter och undervisningsstrategier' [Experienced teachers' insights and strategies in history teaching]. Licentiate thesis, Umeå University. http://urn.kb.se/resolve?urn=urn:nbn:se:umu:diva-1976 (accessed 14 January 2021).

Pajares, F. (1992) 'Teachers' beliefs and educational research: Cleaning up a messy construct'. Review of Educational Research, 62 (3), 307-32. https://doi.org/10.3102/00346543062003307.

Palys, T. (2008) 'Basic research'. In Given, L.M. (ed.), The Sage Encyclopedia of Qualitative Research Methods. Vol. 1. Thousand Oaks, CA: Sage, 57-9.

Reisman, A. (2012) 'Reading like a historian: A document-based history curriculum intervention in urban high schools'. Cognition and Instruction, 30 (1), 86-112. https://doi.org/10.1080/07370008. 2011.634081.

Seixas, P. (2008) 'Scaling Up' the Benchmarks of Historical Thinking: A Report on the Vancouver Meetings, February 14-15, 2008. University of British Columbia. http://historicalthinking.ca/sites/ default/files/files/docs/Scaling\%20Up\%20Meeting\%20Report.pdf (accessed 30 December 2020).

Seixas, P. and Morton, T. (2013) The Big Six Historical Thinking Concepts. Toronto: Nelson Education.

Shulman, L.S. (1986) 'Those who understand: Knowledge growth in teaching'. Educational Researcher, 15 (2), 4-14. https://doi.org/10.3102/0013189X015002004.

Sigurgeirsson, I., Eiríksdóttir, E. and Jóhannesson, I.Á. (2018) 'Kennsluaðferðir í 130 kennslustundum í framhaldsskólum' [Teaching strategies in 130 lessons in upper secondary schools]. In Jóhannsdóttir, P.J. and Porgeirsdóttir, H. (eds), Framhaldsskólinn í brennidepli. Netla, veftímarit um uppeldi og menntun. https://doi.org/10.24270/serritnetla.2019.9.

Stradling, R. (2003) Multiperspectivity in History Teaching: A guide for teachers. Council of Europe. https://rm.coe.int/1680493c9e (accessed 25 January 2021).

Trautwein, U., Merkt, M., Neureiter, H., Schwan, S., Schreiber, W., Wagner, W., Waldis, M., Werner, M., Ziegler, B., Zuckowski, A., Bertram, C., Von Borries, B., Brauch, N., Hirsch, M., Klausmeier, K., Körber, A., Kühberger, C. and Meyer-Hamme, J. (2017) Kompetenzen historischen Denkens erfassen. Konzeption, Operationalisierung und Befunde des Projekts 'Historical Thinking Competencies in History' (HiTCH). Münster: Waxmann.

Tuithof, H. (2017) 'The Characteristics of Dutch Experienced History Teachers' PCK in the Context of a Curriculum Innovation'. PhD thesis, Utrecht University. https://dspace.library.uu.nl/ handle/1874/351524 (accessed 14 January 2021).

Tuithof, H., Logtenberg, A., Bronkhorst, L., Van Drie, J., Dorsman, L. and Van Tartwijk, J. (2019) 'What do we know about the pedagogical content knowledge of history teachers: A review of empirical research'. Historical Encounters: A Journal of Historical Consciousness, Historical Cultures, and History Education, 6 (1), 72-95.

Van Boxtel, C. and Van Drie, J. (2013) 'Historical reasoning in the classroom: What does it look like and how can we enhance it?' Teaching History, 150, 44-52.

Van Boxtel, C. and Van Drie, J. (2017) 'Engaging students in historical reasoning: The need for dialogic history education'. In Carretero, M., Berger, S. and Grever, M. (eds), Palgrave Handbook of Research in Historical Culture and Education. London: Palgrave Macmillan, 573-89. https://doi.org/10.1057/978-1-137-52908-4_30.

Van Boxtel, C. and Van Drie, J. (2018) 'Historical reasoning: Conceptualizations and educational applications'. In Metzger, S.A. and McArthur Harris, L. (eds), The Wiley International Handbook of History Teaching and Learning. Hoboken, NJ: Wiley-Blackwell, 149-76. https://doi.org/10.1002/9781119100812.ch6.

Van Boxtel, C., Voet, M. and Stoel, G. (in press) 'Inquiry learning in history'. In Chinn, C., Duncan, R., Goldman, S. and Kapur, M. (eds), International Handbook of Inquiry and Learning Across Disciplines and Contexts. Taylor and Francis. 
Van Drie, J. and Van Boxtel, C. (2008) 'Historical reasoning: Towards a framework for analyzing students' reasoning about the past'. Educational Psychology Review, 20, 87-110. https://doi.org/10.1007/s10648-007-9056-1.

Van Nieuwenhuyse, K., Roose, H., Wils, K., Depaepe, F. and Verschaffel, L. (2017) 'Reasoning with and/or about sources? The use of primary sources in Flemish secondary school history education'. Historical Encounters: A Journal of Historical Consciousness, Historical Cultures, and History Education, 4 (2), 48-70.

VanSledright, B. and Limón, M. (2006) 'Learning and teaching social studies: A review of cognitive research in history and geography'. In Alexander, P. and Winne, P. (eds), The Handbook of Educational Psychology. 2nd ed. Mahwah, NJ: Lawrence Erlbaum Associates, 545-70.

VanSledright, B. and Reddy, K. (2014) 'Changing epistemic beliefs? An exploratory study of cognition among prospective history teachers'. Revista Tempo e Argumento, 6 (11), $28-68$.

Virta, A. (2002) 'Becoming a history teacher: Observations on the beliefs and growth of student teachers'. Teaching and Teacher Education, 18 (6), 687-98. https://doi.org/10.1016/S0742051X(02)00028-8.

Voet, M. and De Wever, B. (2016) 'History teachers' conceptions of inquiry-based learning, beliefs about the nature of history, and their relation to the classroom context'. Teaching and Teacher Education, 55, 57-67. https://doi.org/10.1016/j.tate.2015.12.008.

Wansink, B., Akkerman, S. and Wubbels, T. (2016) 'The Certainty Paradox of student history teachers: Balancing between historical facts and interpretation'. Teaching and Teacher Education, 56, 94-105. https://doi.org/10.1016/j.tate.2016.02.005.

Wiley, J. and Voss, J.F. (1996) 'The effects of "playing historian" on learning in history'. Applied Cognitive Psychology, 10 (7), 63-72. https://doi.org/10.1002/(SICI)10990720(199611)10:7<63::AID-ACP438>3.0.CO;2-5.

Wineburg, S. (1991) 'Historical problem solving: A study of the cognitive processes used in the evaluation of documentary and pictorial evidence'. Journal of Educational Psychology, 83 (1), 73-87. https://doi.org/10.1037/0022-0663.83.1.73.

Yilmaz, K. (2008) 'Social studies teachers' conceptions of history: Calling on historiography'. The Journal of Educational Research, 101 (3), 158-76. https://doi.org/10.3200/JOER.101.3.158-176. 